\title{
UNILATERAL LAMINOTOMY FOR BILATERAL MICRODECOMPRESSION OF STENOSIS OF THE LUMBAR CANAL
}

\author{
LAMINOTOMIA UNILATERAL PARA MICRODESCOMPRESSÃO BILATERAL \\ DE ESTENOSE DO CANAL LOMBAR
}

LAMINOTOMÍA UNILATERAL PARA MICRODESCOMPRESIÓN BILATERAL DE

LA ESTENOSIS DEL CANAL LUMBAR

GuILHERME GontiJo SOARES ${ }^{1}$

\begin{abstract}
With the aging of the world population, the treatment of stenosis of the lumbar canal has become an important issue in addressing degenerative diseases of the spine. The prevalence of this disease tends to increase as the number of surgeries and the impact on health care costs. This paper aims to describe in detail the technique of unilateral laminotomy for bilateral microdecompression (ULBM) of stenosis of the lumbar canal (LSC) and current clinical results, including their advantages, disadvantages and common complications, based on the available literature. Important studies have shown evidence that surgical treatment for LSC is more effective than the conservative, but without evaluating ULBM. Several studies on ULBM have been conducted since the 90s, showing the results of this technique, however, most of these are case series, retrospective studies or cohorts without proper control group or with weak statistical analysis to prove some evidence. A double-blind randomized clinical trial was found, but with short follow-up. We conclude that studies are needed with more solid evidence to prove the effectiveness of ULBM despite the clinical results being similar to those of classical surgery found in the literature.
\end{abstract}

Keywords: Spinal stenosis; Cost-benefit analysis; Microsurgery; Surgery; Anatomy.

\section{RESUMO}

Com o envelhecimento da população mundial, o tratamento da estenose do canal lombar tornou-se uma questão importante na abordagem das doenças degenerativas da coluna. A prevalência dessa patologia tende a aumentar, assim como o número de cirurgias e o impacto sobre os custos da saúde. Este trabalho tem como objetivo descrever com detalhes a técnica de laminotomia unilateral para microdescompressão bilateral (LUMB) de estenose do canal lombar (ECL) e os resultados clínicos atuais, incluindo suas vantagens, desvantagens e complicações comuns, com base na literatura disponível. Estudos importantes demonstraram evidências de que o tratamento cirúrgico da ECL é mais eficaz do que o conservador, porém sem avaliar a LUMB. Vários trabalhos sobre LUMB foram realizados desde a década de 90, mostrando os resultados dessa técnica, porém, a maioria consiste em séries de casos, estudos retrospectivos, ou coortes sem grupo controle adequado ou com análises estatísticas fracas para provar alguma evidência. Foi encontrado um ensaio clínico duplo cego randomizado, porém com período curto de acompanhamento. Conclui-se que são necessários trabalhos com evidências mais sólidas para comprovar a eficácia da LUMB, apesar de seus resultados clínicos serem semelhantes aos da cirurgia clássica encontrados na literatura especializada.

Descritores: Estenose espinal; Análise custo-benefício; Microcirurgia; Cirurgia; Anatomia.

\section{RESUMEN}

Con el envejecimiento de la población mundial, el tratamiento de la estenosis del canal lumbar se ha convertido en un tema importante en el tratamiento de las enfermedades degenerativas de la columna vertebral. La prevalencia de esta enfermedad tiende a aumentar y también el número de operaciones y el impacto en los costos de salud. Este trabajo tiene por meta describir en detalle la técnica de laminotomía unilateral para microdescompresión bilateral (LUMB) de la estenosis del canal lumbar (ECL) y los resultados clínicos actuales, incluyendo sus ventajas, desventajas y complicaciones comunes, con base en la literatura disponible. Importantes estudios han mostrado evidencia de que el tratamiento quirúrgico para la ECL es más eficaz que el consenvador, pero sin evaluar LUMB. Varios trabajos se han realizado sobre LUMB desde los años 90, los cuales demuestran los resultados de esta técnica, sin embargo, la mayoría de ellos son series de casos, estudios retrospectivos o cohortes sin grupo de control adecuado o con un débil análisis estadístico para probar algunas evidencias. Se encontró un ensayo clínico aleatorizado y doble ciego, pero con seguimiento corto. Se concluye que son necesarios trabajos que presenten evidencia más sólida para demostrar la eficacia de la LUMB, a pesar de sus resultados clínicos muy semejantes a los resultados de la cirugía clásica encontrados en la literatura especializada.

Descriptores: Estenosis espinal; Análisis costo-beneficio; Microcirugía; Cirugía; Anatomía.

\section{INTRODUCTION}

With the aging of the world's population, particularly in Europe, the United States, and other developed and developing countries, like Brazil, the treatment of lumbar spinal stenosis (LSS) has become an important issue in the approach to degenerative diseases of the spine. This pathology is the most common motive for lumbar spine surgery in people older than 65 years of age in the United States. ${ }^{1}$ The prevalence of LSS and its associated costs should parallel the growth in the number of people 60 years old or older, which is expected to quadruple to approximately 2 billion worldwide by the year 2050.1

In the United States, the incidence of surgery for LSS increased eightfold from 1979 to 1992 . $^{2}$ Studies with high levels of evidence

1. Hospital da Unimed, Belo Horizonte, MG, Brazil.

Study conducted at Hospital Madre Tereza, Belo Horizonte and Hospital da Unimed, Belo Horizonte, MG, Brazil

Correspondence: Rua dos Guajajaras 556 - Centro, Belo Horizonte, MG, Brasil. 30180-100. guigsoares@gmail.com 
have proven that surgical decompression is more effective, both from the clinical perspective and in the cost-benefit analysis, when compared to conservative therapy. ${ }^{3-5}$

The classic surgical procedures used to treat LSS result in the destruction or dysfunction of the zygapophysial joints, posterior ligamentous complex, and paravertebral muscles, leading to instability of the vertebral segment involved. ${ }^{6-8}$

Over the last two decades, minimally invasive procedures have emerged as treatment alternatives for various spine pathologies. These procedures have the common goal of avoiding the biomechanical complications associated with some traditional surgical methods. ${ }^{7}$ The Unilateral Laminotomy for Bilateral Microcompression (ULBM) was first described in the 1980s, and was modified, reproduced, and published by Weiner et al. ${ }^{6}$ and McCullosh et al. ${ }^{8}$ and other European authors in the 1990s. ${ }^{9}$ This procedure is characterized by the fact that it maintains the integrity and stability of the spine, preserving the tissues not involved in the physiopathology of LSS, and providing adequate decompression of the neural structures located in the spinal canal. ${ }^{7}$

\section{METHODOLOGY}

The objective of this study is to describe the details of the Unilateral Laminotomy technique for Bilateral Microcompression of Lumbar Spinal Stenosis and the current clinical results, including its advantages, disadvantages, and common complications, based on the available literature.

To this end, a search of articles in the CAPES portal was conducted using the terms "Microcompression + spinal + stenosis", "Microsurgical + spinal + stenosis", and "unilateral laminotomy for bilateral decompression", without any date restrictions, resulting in 55 articles for the first search (23 after eliminating duplicates), 164 for the second (83 after eliminating duplicates), and 135 for the third (55 after eliminating duplicates). Of these, only those that presented the clinical results of the procedure in question, with detailed descriptions or reviews of the topic, were selected.

\section{RESULTS}

The patient is positioned in ventral decubitus, the standard position for spinal procedures. Decompression is achieved by partial resection of the upper and lower parts of the laminar arch of the affected level for one or more levels or by hemilaminectomy by decompression of the two consecutive levels, partial medial resection of the ipsilateral facet joints and of the central part of the base of the spinous process, and complete removal of the ligamentum flavum. The contralateral ligamentum flavum and the medial portion of the contralateral facet joint are also removed for contralateral decompression. 6,8,9 This process allows visualization of the entire posterior surface of the dural sac, the contralateral nerve root, and the foramen. If necessary, discectomy and foraminotomy can be performed. (Figures 1, 2, 3 and 4)

In a biomechanical study using swine models, published in BMC Musculoskeletal Disorders in 2008, the authors demonstrated that during movements of flexion, displacement of the intervertebral segments submitted to total laminectomy in segments L4-L5 was significantly greater than in those that were intact or had undergone bilateral laminectomy $(P=0.0000963$ and $P=0.0000963$, respectively). Moreover, no differences were found between the intact and bilateral laminotomy groups $(P>0.05)$. In movements of extension, there was no significant difference in displacement among the three groups. ${ }^{10}$

In 1999, Weiner et al. ${ }^{6}$ after describing the ULBM technique in detail, presented the results of their case series. Thirty patients underwent surgery and prospective follow-up. Of these, 16 were women and 14 were men, with an average age of 68. Following surgery, the average neurogenic claudication score rose from 32 to 67 on a scale with a maximum score of 100 (with 100 representing the asymptomatic patient). Twenty-six (26) patients thought that their outcomes were good to excellent. No intraoperative com- plications were observed. Four (4) patients required drainage of abundant wound secretions, one of which, when cultured, tested positive for $S$. aureus. ${ }^{6}$

In a prospective analysis, Kato et al. ${ }^{11}$ identified facet joint synovial cysts in 38 (16.5\%) out of 230 patients who had undergone ULBM during one year of follow-up. Twenty-four (24) of them had

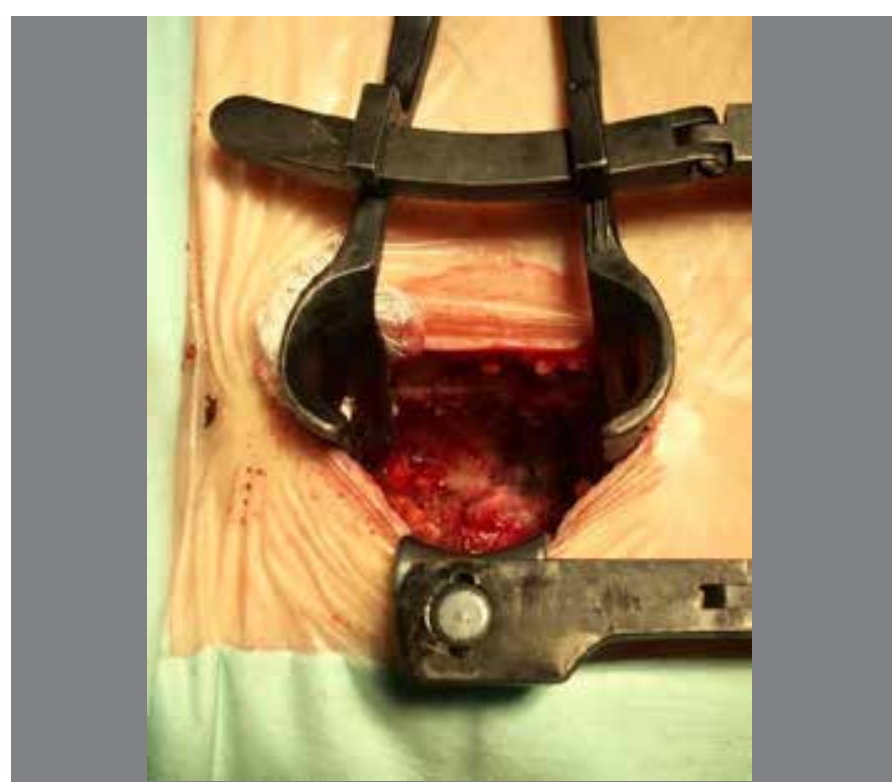

Figure 1. LUMB access with specular retractors.

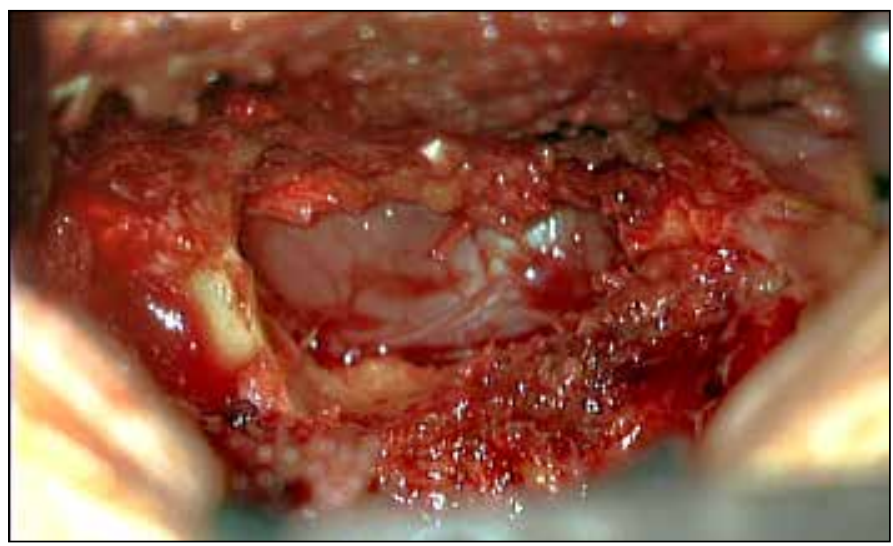

Figure 2. After partial laminectomy, removal of the ligamentum flavum and part of the facet joint.

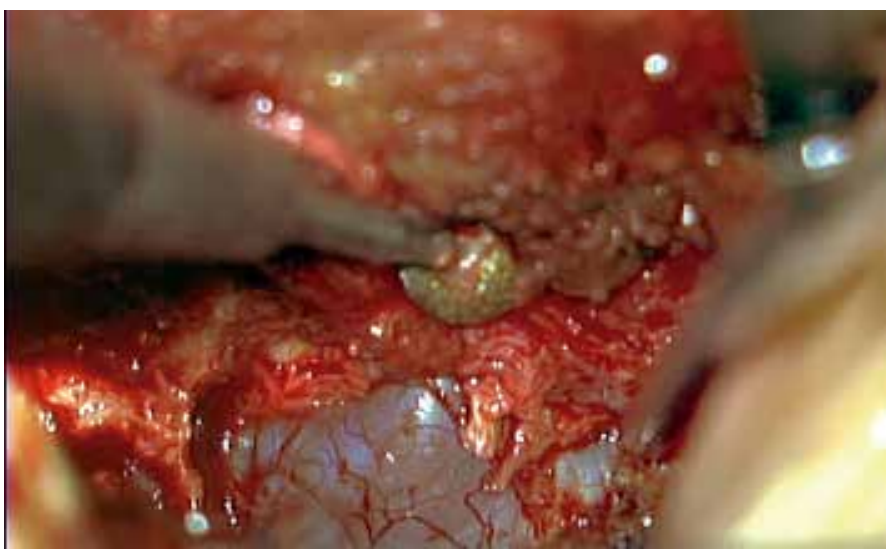

Figure 3. Resection of the base of the spinous process with a diamond-tipped burr. 


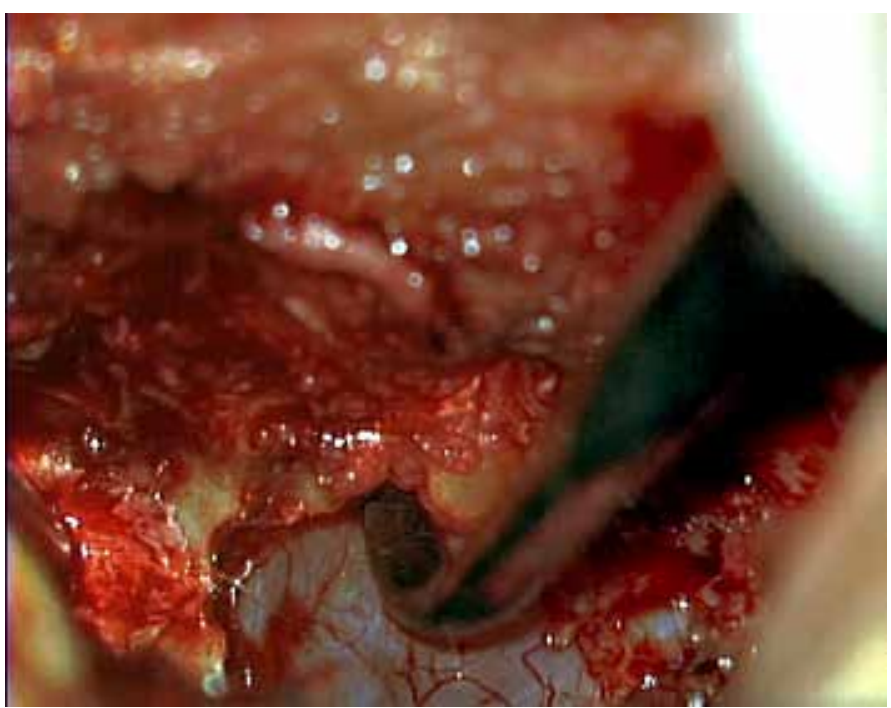

Figure 4. Contralateral palpation, over the top.

cysts within the first 3 months. In 10 patients, the cysts were spontaneously resolved within one year after surgery. The average Japanese Orthopedic Association Score (JOA) of patients with cysts at one year following surgery was significantly less than that of patients without cysts. This result was generated by the presence of lower back pain that did not improve, despite conservative treatment. Most patients with spontaneous disappearance of cysts still had no symptoms a year later. The preoperative risk factors for cyst formation were instability, anterior-posterior translation greater than $3 \mathrm{~mm}$ in flexion-extension (OR 2.47, $\mathrm{P}=0.26$ ), scoliotic disc with wedge $>5^{\circ}$ in $\mathrm{AP}$ radiograph (OR 2.23, $\mathrm{P}=0.048$ ), and change in sagittal balance, and distance $>50 \mathrm{~mm}$ from the promontory to the C7 plumb line (OR 2.22, $\mathrm{P}=0.045) .^{11}$

In a 5-year follow-up published in 2011, Toyoda $\mathrm{H}$ et al. presented the following findings from a series of 57 patients (27 with LSS without instability, 20 with degenerative spondylolisthesis (DS), and 10 with degenerative lumbar scoliosis (DLS) with neurogenic claudication who underwent ULMB. The average JOA score was 13.8 \pm 3.6 points prior to surgery, improving to $24.9 \pm 3.1$ points after three months and $22.6 \pm 4.7$ points at the end of follow-up. There were no differences between the disease groups. Four patients $(7 \%)$ were reoperated, two with DS and two with DLS. The percentages of preoperative listhesis with LSS, DS, and DLS were $0.4 \% \pm 2.2 \%$, $13.2 \% \pm 5.9 \%$, and $0.0 \% \pm 1.3 \%$, respectively, while the degrees of progression of the listhesis at the last follow-up were 1.2\% $\pm 3.1 \%$ $2.4 \% \pm 4 ., 7 \%$, and $0.0 \% \pm 0.0 \%$, respectively, without differences between the groups. ${ }^{12}$

Costa et al. ${ }^{13}$ published a case series with a five-year follow-up, conducted with 374 (79.1\% - 183 men and 191 women) of the 473 patients having undergone ULBM between 2000 and 2004. Of these, 285 patients $(76.2 \%)$ had stenosis at a single level, 86 (22.9\%) at two levels, and $3(0.9 \%)$ at three levels. Three hundred and twenty-nine patients (87.9\%) presented clinical benefits, defined as neurological improvement (absence of neurogenic claudication), improvement in the Visual Analog Scale for Pain (with the average decreasing from 8.9 to $4.2, \mathrm{p}<0.0001$ ), and in the Prolo economic and functional scale $(2 \pm 1$ before surgery to $4 \pm 1$, in both areas, $p<0.0001)$. Of the 95 patients with radiculopathy - sensory or motor deficit at admission, 38 (40\%) still had some deficit. Additional radicular dysfunction was not observed postoperatively in any case of the series. Only three patients $(0.8 \%)$ had segmental instability at the level treated, but without the need for surgical stabilization, and all were treated conservatively with improvement. ${ }^{13}$

In a retrospective clinical follow-up of 133 patients who underwent ULBM between 1994 and 1999, Oertel et al. ${ }^{14}$ confirmed that $130(97.7 \%)$ showed immediate improvement following surgery. Ninety-four (92.2\%) of the 102 patients available for follow-up exams for a period of at least four years maintained the improvements and $85.3 \%$ had good to excellent operative outcomes. The incidence of complications was $9.8 \%$. New procedures were required to address surgical complications in three patients, to treat new stenosis in seven patients, and for vertebral instability in two patients, corresponding to a total reoperation rate of $11.8 \%{ }^{14}$

In a prospective cohort study, Papavero et al. ${ }^{2}$ published the following results: reduction of pain in $85.9 \%$ of patients one week after surgery, and reduction of postoperative use of analgesics compared to preoperative use, with discontinuation of non-opioid use in $38 \%$ and of opioid use in $74 \%$, while consumption of NSAIDs increased by $13 \%$. One year after surgery, the pain remained decreased in $83.9 \%$ of the patients, and walking performance improved by $92.2 \%$. A Body Mass Index greater than 30 was the only negative prognostic factor for pain reduction $(P=0.012)$ and improvement in the neurogenic claudication score $(P=0.019)$. Seven reoperations were performed, 5 during the same hospitalization ( 3 for insufficient decompression, 1 because the surgery was performed on the wrong level, and 1 to treat a liquoric fistula). The other two were performed within the first year to reoperate the same level. ${ }^{2}$

Twenty-one patients (10 men, 11 women) between 53 and 82 years of age $(64.1 \pm 8.9$ years) were followed up for a minimum period of three years (36-69 months) by Yang et al.. ${ }^{15}$ Two patients were reoperated during follow-up. The average JOA score improved significantly in a comparison of preoperative and last follow-up evaluation values, with the exception of already existing lower back pain. There were no significant differences between preoperative and postoperative radiological findings. Thirteen patients $(61.9 \%)$ had good to excellent results. Two patients underwent subsequent lumbar surgery consisting of arthrodesis to treat foraminal stenosis and lumbar instability with persistent lower back pain. Two (10.5\%) surgery-related complications were observed: dehiscence of a suture, and a deep infection of the surgical wound. Both patients recovered without sequelae. ${ }^{15}$

The only randomized clinical trial found comparing ULBM with Laminectomy showed significant improvements in the Oswestry Disability Index (ODI) and the Visual Analog Scale for Pain (VAS) for both interventions ( $p<0.001$ for both groups). Furthermore, the patients treated with ULBM had a significantly better improvement in the VAS scale $(p=0.013)$, but not in the ODI $(p=0.055)$ when compared with the patients who underwent laminectomies. The group treated with ULBM had shorter postoperative hospitalizations (55.1 vs. 100.8 hours, $p=0.0041$ ) and shorter mobilization times (15.6 vs. 33.3 hours, $p<0.001$ ) and used fewer opioids for postoperative pain (51.9\% vs. $15.4 \%, p=0.046) .{ }^{16}$

\section{DISCUSSION}

Most studies of surgical treatment of LSS demonstrate that both ULBM and laminectomy can significantly improve the ODI, VAS, Quality of Life Questionnaires, and satisfaction index among the patients. ${ }^{2}$ They also present similar reoperation and complication rates as quoted in a 2012 review article by Smith and Fessler. ${ }^{17}$

Laminectomy presents negative characteristics such as the removal of a large bone mass and lesion of the posterior ligamentous complex and the paravertebral musculature, which can lead to instability in flexion, weakness, and paraspinal muscular atrophy, and also leaves a large dead space, the perfect medium for bacterial colonization and/or scarring around the nerve and the dura mater. These complications can lead to chronic pain, reducing the functional outcome of the surgery. ${ }^{6}$ It is the standard procedure for treating LSS, but it is gradually losing ground to ULBM. ${ }^{18}$

In all the works analyzed, ULBM can achieve good to excellent results in most patients. Furthermore, some studies show a reduction in surgical time, less blood loss, narcotics use, hospitalization time, and time to initiate mobilization. ${ }^{19}$ This is a great advantage given that the population subjected to this treatment is elderly and more susceptible to postoperative complications, such as deep vein thrombosis, urinary tract infections, cardiorespiratory problems, and pulmonary embolism 
among others, which also impact treatment costs.

The possible disadvantages of ULBM include difficulty in manipulating the instruments through a small portal, which can increase the risk of dural sac lesions and liquoric fistulae, higher rates of recurrence and of reoperation because of inadequate decompression, and an increase in surgical time due to a steep learning curve. ${ }^{17}$

However, this review reveals a lack of studies with the adequate control groups and methodological designs to compare effectiveness between ULBM and laminectomy. Additionally, the disparity between the variables measured, follow-up time, size and heterogeneity of the samples published to date makes a comparison of study results unfeasible.

\section{FINAL CONSIDERATIONS}

The articles reviewed in this study show that in general terms ULBM is a safe technique that is effective in the long term in the treatment of LSS, even in high risk patients and patients with multilevel stenosis. The few complications include dural lesion, nerve root lesion, and the need to reoperate. ${ }^{19}$

We concluded that studies with better evidence are necessary to confirm the efficacy of ULBM, even though its clinical results are similar to those of classic surgery found in the specialized literature.

All authors declare no potential conflict of interest concerning this article.

\section{REFERENCES}

1. Markman JD, Gaud KG. Lumbar spinal stenosis in older adults: current understanding and future directions. Clin Geriatr Med. 2002;24(2):369-88.

2. Papavero L, Thiel M, Fritzsche E, Kunze C, Westphal M, Kothe R. Lumbar spinal stenosis: prognostic factors for bilateral microsurgical decompression using a unilateral approach. Neurosurgery. 2009;65(Suppl 6):182-7.

3. Tosteson AN, Tosteson TD, Lurie JD, Abdu W, Herkowitz H, Andersson G, et al. Comparative effectiveness evidence from the spine patient outcomes research trial: surgical versus nonoperative care for spinal stenosis, degenerative spondylolisthesis, and intervertebral disc herniation. Spine (Phila Pa 1976). 2011;36(24):2061-8.

4. Tosteson AN, Skinner JS, Tosteson TD, Lurie JD, Andersson GB, Berven S, et al. The cost effectiveness of surgical versus nonoperative treatment for lumbar disc herniation over two years: evidence from the Spine Patient Outcomes Research Trial (SPORT). Spine (Phila Pa 1976). 2008;33(19):2108-15.

5. Weinstein JN, Tosteson TD, Lurie JD, Tosteson AN, Blood E, Hanscom B, et al. Surgical versus nonsurgical therapy for lumbar spinal stenosis. N Engl J Med. 2008;358(8):794-810.

6. Weiner BK, Walker M, Brower RS, McCulloch JA. Microdecompression for lumbar spinal canal stenosis. Spine (Phila Pa 1976). 1999;24(21):2268-72.

7. Banczerowski P, Czigléczki G, Papp Z, Veres R, Rappaport HZ, Vaida J. Minimally invasive spine surgery: systematic review. Neurosurg Rev. 2015;38(1):11-26.

8. McCulloch JA, Young PA. Essentials of spinal microsurgery. Philadelphia: Lippincott-Raven; 1998

9. Spetzger U, Bertalanffy $H$, Naujokat $C$, von Keyserlingk DG, Gilsbach JM. Unilateral laminotomy for bilateral decompression of lumbar spinal stenosis. Part I: Anatomical and surgical considerations. Acta Neurochir (Wien). 1997;139(5):392-6.

10. Tai CL, Hsieh PH, Chen WP, Chen LH, Chen WJ, Lai PL. Biomechanical comparison of lumbar spine instability between laminectomy and bilateral laminotomy for spinal stenosis syndrome - an experimental study in porcine model. BMC Musculoskelet Disord. 2008;9:84

11. Kato M, Konishi S, Matsumura A, Hayashi K, Tamai K, Shintani K, et al. Clinical characteristics of intraspinal facet cysts following microsurgical bilateral decompression via a unilateral approach for treatment of degenerative lumbar disease. Eur Spine J. 2013;22(8):1750-7.

12. Toyoda H, Nakamura H, Konishi S, Dohzono S, Kato M, Matsuda H. Clinical outcome of microsurgical bilateral decompression via unilateral approach for lumbar canal stenosis: minimum five-year follow-up. Spine (Phila Pa 1976). 2011;36(5):410-5.

13. Costa F, Sassi M, Cardia A, Ortolina A, De Santis A, Luccarell G, Fornari M. Degenerative lumbar spinal stenosis: analysis of results in a series of 374 patients treated with unilateral laminotomy for bilateral microdecompression. J Neurosurg Spine. 2007;7(6):579-86.

14. Oertel MF, Ryang YM, Korinth MC, Gilsbach JM, Rohde V. Long-term results of microsurgical treatment of lumbar spinal stenosis by unilateral laminotomy for bilateral decompression. Neurosurgery. 2006;59(6):1264-9.

15. Yang SM, Park HK, Chang JC, Kim RS, Park SQ, Cho SJ. Minimum 3-year outcomes in patients with lumbar spinal stenosis after bilateral microdecompression by unilateral or bilateral laminotomy. J Korean Neurosurg Soc. 2013;54(3):194-200.

16. Mobbs RJ, Li J, Sivabalan P, Raley D, Rao PJ. Outcomes after decompressive laminectomy for lumbar spinal stenosis: comparison between minimally invasive unilateral laminectomy for bilateral decompression and open laminectomy: clinical article. J Neurosurg Spine. 2014;21(2):179-86.

17. Smith ZA, Fessler RG. Paradigm changes in spine surgery - evolution of minimally invasive techniques. Nat Rev Neurol. 2012;8:443-50.

18. Mayer HM, Korge A. Microsurgical decompression of degenerative lumbar spinal stenosis. Eur Spine J. 2009;18:1989-90.

19. Banczerowski P, Czigléczki G, Papp Z,Veres R, Rappaport HZ, Vajda J. Minimally invasive spine surgery: systematic review. Neurosurg Rev. 2015;38:11-26. 